\title{
Austenitic stainless steels layers deposited by laser cladding on a mild steel: realization and characterization
}

\author{
F. FOUQUET, P. SALLAMAND, J.P. MILLET ${ }^{*}$, A. FRENK ${ }^{* *}$ and J.D. WAGNIERE** \\ GEMPPM/CALFETMAT, INSA, 69621 Villeurbanne cedex, France \\ * Physicochimie Industrielle, INSA, 69621 Villeurbanne cedex, France \\ ${ }^{* *}$ CTML, Ecole Polytechnique Fédérale de Lausanne (EPFL), 1015 Lausanne, Switzerland
}

\begin{abstract}
The present work reports on 18-10 (AISI 304 grade) and 18-12-Mo (AISI 316 grade) stainless steel coatings produced by laser powder cladding technique.Clad layers of uniform thicknesses have been produced through partially overlapping single cladding tracks. The clad layers thus obtained show excellent adherence, few porosities and good chemical homogeneity. The microstructure is dendritic or most often cellular. The 304 clad layers are free of cracks and have a structure mainly austenitic with a certain amount of $\delta$-ferrite. The 316 clad layers show always cracks and their structure is almost fully austenitic. Primary solidification of $\delta$ phase seems thus favourable to prevent hot cracking of the austenitic stainless steels layers. The corrosion resistance of the crack-free 304 clad layers has been tested in various saline media. In every case, the coatings exhibit a very good uniform corrosion resistance.
\end{abstract}

\section{INTRODUCTION}

Stainless steel coatings can be produced by laser melting of a twin nickel and chromium electrodeposit on a mild steel [1]. However this laser alloying technique requiring predeposits is a very expensive method, and other techniques using laser must then be considered. Laser cladding by the blown powder method is a cheaper deposition technique capable of producing wear and corrosion resistant layers $[2,3,4]$. The present work aimed to deposit clad layers of AISI 304 and AISI 316 austenitic stainless steels on a carbon steel substrate and to characterize the main metallurgical features of these layers.

\section{EXPERIMENTAL PROCEDURE}

The stainless steel powders of the two grades (AISI 304 and AISI 316) had a grain size of between 50 and $100 \mu \mathrm{m}$. The chemical compositions of the powder are given in table 1 . The substrate was a 0.15 wt $\%$ carbon steel. The samples were of parallelepiped form $\left(70 \times 35 \times 20 \mathrm{~mm}^{3}\right)$. The cladding powders were transported in pressurised argon and injected under the laser beam, near the substrate surface with an injection angle, with respect to the horizontal, of $55^{\circ}$ as shown on figure 1 . A $1.5 \mathrm{~kW}$ continuous wave $\mathrm{CO}_{2}$ laser was used. Clad layers of uniform thicknesses - about 600 to $700 \mu \mathrm{m}$ were produced through partially overlapping single cladding tracks. The following processing parameters were used : beam diameter 3

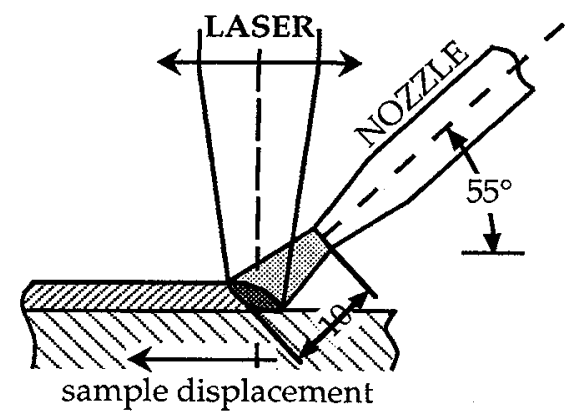

Figure 1: Schematic drawing of the experimental process 
to $5 \mathrm{~mm}$, injection nozzle diameter $2 \mathrm{~mm}$, inter-track advance 1.0 to $1.6 \mathrm{~mm}$, scanning speed 100 to $700 \mathrm{~mm} / \mathrm{min}$ and powder feeding rate 1.5 to $6.0 \mathrm{~g} / \mathrm{min}$.

The microstructure was studied by means of optical microscopy, after etching in appropriate reagents. Chemical composition was investigated using EDS microanalysis on a scanning electron microscope. X-ray diffraction structure determinations were also carried out. The corrosion behaviour has been tested by means of electrochemical techniques in four different aqueous saline media : deaerated 0.1 $\mathrm{M} \mathrm{Na} 2 \mathrm{SO}_{4}$ (neutral and $\mathrm{pH}=3$ ) and $\approx 0.5 \mathrm{M} \mathrm{NaCl}$ (aerated and deaerated).

Table 1: Chemical composition of the powders and of the clad layers (weight \%)

\begin{tabular}{|c|c|c|c|c|c|c|c|c|}
\hline Analysis & $\mathrm{Fe}$ & $\mathrm{Cr}$ & $\mathrm{Ni}$ & $\mathrm{Si}$ & $\mathrm{Mn}$ & $\mathrm{Mo}$ & $\mathrm{C}$ & others \\
\hline powder 304 & 67.4 & 19.7 & 11.4 & 1.1 & 0.3 & - & 0.06 & $\approx 0.1$ \\
\hline 304 clad layer & 68.3 & 19.2 & 10.9 & 1.0 & 0.4 & - & - & $\approx 0.3$ \\
\hline powder 316 & 64.6 & 17.1 & 12.8 & 1.0 & 2.0 & 2.2 & 0.1 & $\approx 0.2$ \\
\hline 316 clad layer & 65.4 & 16.6 & 12.7 & 1.1 & 1.8 & 2.3 & - & $\approx 0.1$ \\
\hline
\end{tabular}

\section{MICROSTRUTURAL CHARACTERIZATION}

For both grades of stainless steels the clad layers obtained had a uniform thickness and showed few porosities except sometimes for cavities between adjacent overlapped tracks near the cladding subtrate interfaces. The substrate was melted to a depth of less than $10 \mu \mathrm{m}$ in such a way that the bounding between the clad and the substrate was very good, but the dilution of the cladding material was almost zero. Thus, chemical composition of the clad layers was homogeneous and practically the same as that of the injected powder as shown by EDS chemicaI composition determinations of the main elements reported on table 1.

Nevertheless an important difference was observed between the two stainless steels : with 304 grade the obtained clad layers were free of cracks whereas those obtained with the 316 grade showed always cracks whatever the scanning speed may be as can be seen on figures 2 and 3 .
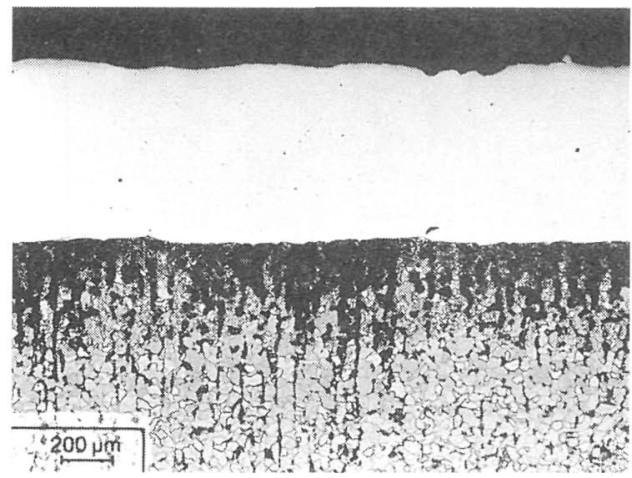

Figure 2 : Cross-section optical micrograph of 304 clad layer ( $3 \%$ nital etching)

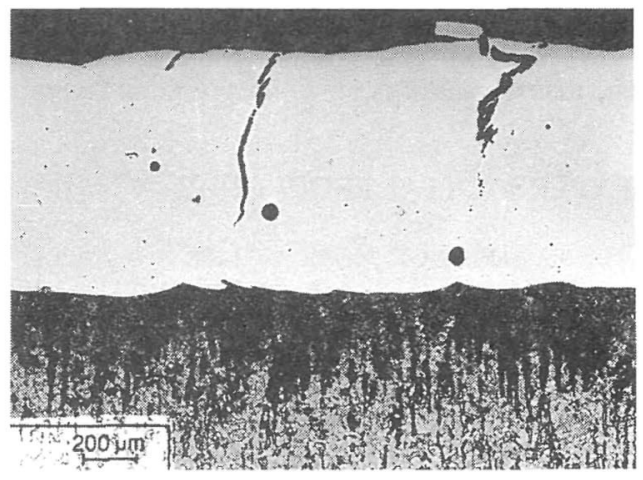

Figure 3 : Cross-section optical micrograph of 316 clad layer ( $3 \%$ nital etching)

X-ray diffraction analysis (fig. 4, 5) revealed that the structure was fully austenitic for the 316 stainless steel layers and mainly austenitic but with a significant amount of $\delta$-ferrite for the 304 layers. Figure 4 also showed a texture effect for austenite in 304 coatings, $\gamma$ (200) peak being 
higher than $\gamma$ (111) one; 316 coatings did not exhibit such a texture effect (fig. 5). Metallographic investigations pointed out that the clad layer microstructure was dendritic or most often cellular with a cell size of between 2 and $10 \mu \mathrm{m}$ as shown on figures 6 and 7. Dendrites and cells had an austenitic structure. In the case of the 304 stainless steel layers $\delta$-ferrite is located at the cells boundaries. However $\delta$-ferrite was not uniformely distributed in the whole layer as revealed on figure 6 where $\delta$-ferrite rich zones appear in black. Indeed, in the heat affected regions, due to track overlapping, $\delta \rightarrow \gamma$ transformation occurs, leading to a fully austenitic structure after cooling, so that two different structures were observed on each side of the cladding / cladding overlapped interface. In the case of the $\mathbf{3 1 6}$ stainless steel layers, some traces of $\delta$-ferrite can be seen at the track interface on figure 7 which shows also clearly a refinement of austenite cells in the heat affected zones (right side on the micrograph). Finally it must be noted that the formation of a significant amount of $\delta$-ferrite during the solidification can be associated with the absence of cracks in clad layers. This is in agreement with the observations done by main authors [5] concerning hot cracking of welded austenitic stainless steels.

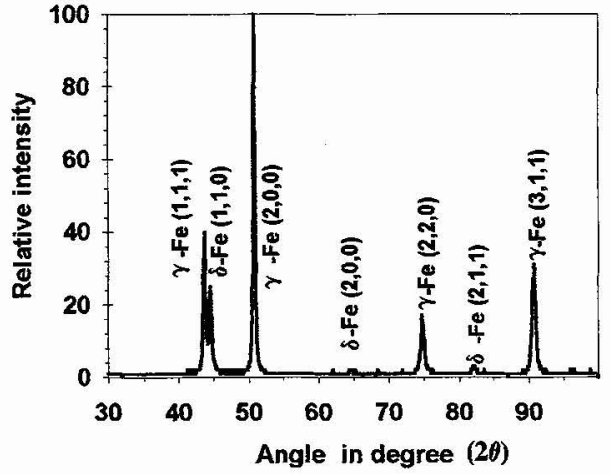

Figure 4 : 304 clad layer X-ray diffraction pattern

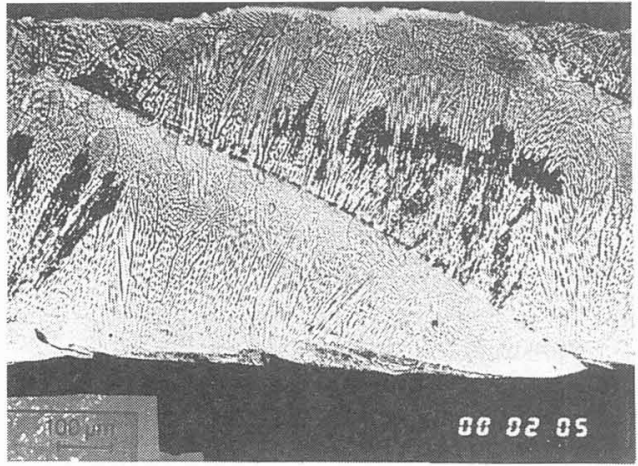

Figure 6 : Cross-section optical micrograph of a 304 clad layer (Catella reagent etching)

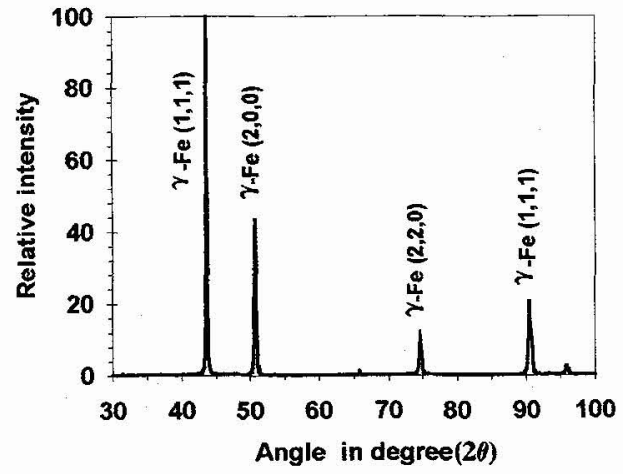

Figure $5: 316$ clad layer $X$-ray diffraction pattern

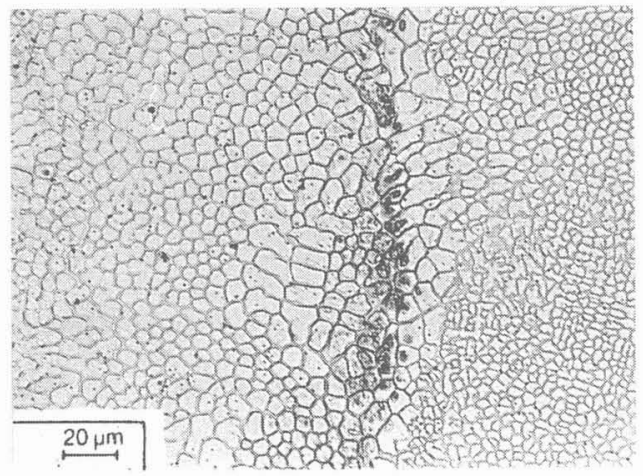

Figure 7 : Surface optical micrograph of a 316 clad layer - tracks interface

(Catella reagent etching)

\section{CORROSION BEHAVIOUR RESULTS}

Corrosion properties have been tested only on the 304 stainless steel clad layers which were free of cracks. Table 2 summarizes the observed results in the various media and gives both the free corrosion potential Ecor, determined after stabilization, and the corrosion current density obtained by extrapolation of the polarization curves recorded at a $1 \mathrm{mV} / \mathrm{s}$ rate, after obtaining stabilized 
Ecor. Table 2 clearly shows that the coated specimens present a good corrosion resistance, as good as massive 304 stainless steel, even better in case of immersion inside neutral aerated $\mathrm{NaCl}$ solution $(30 \mathrm{~g} / \mathrm{l}, \approx 0.5 \mathrm{M})$. This behaviour is even enhanced in case of surface polishing, the clad layer being thick enough to allow this post-treatment. The corrosion potential values are even more noble in this case, maybe due to the elimination of surface impurities, defects or chemical homogeneity lack. Indeed, the laser treatment leads to realize an overlapped coating.

Table 2: Electrochemical measurements

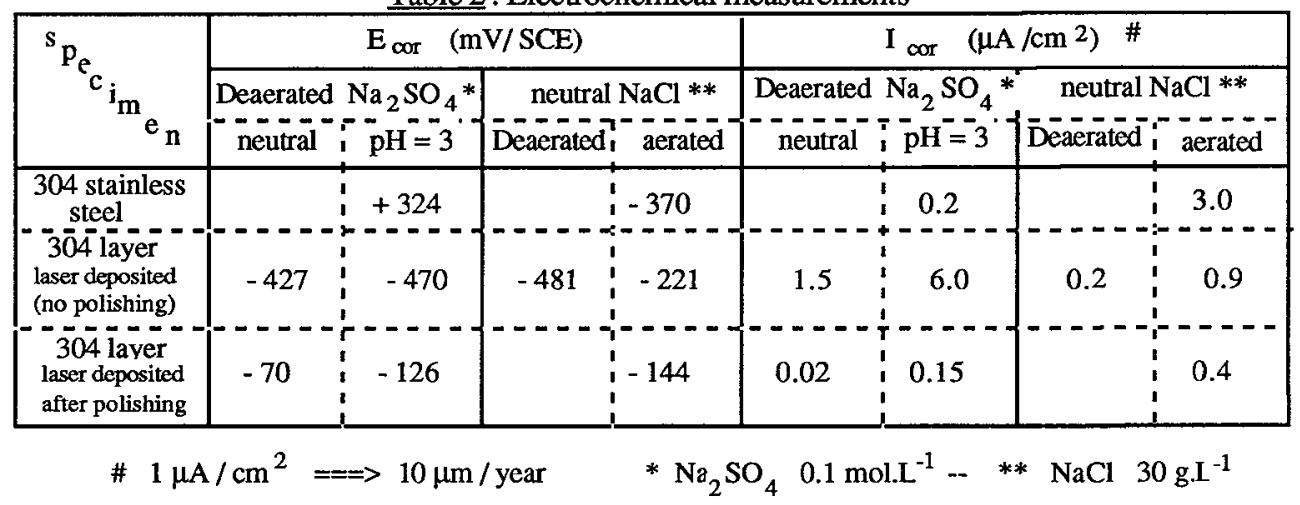

A long immersion test has been carried out in aerated $\mathrm{NaCl}$ solution with a clad 304 layer specimen without polishing. The results are given in table 3 . The Icor values are determined from polarization curves recorded only near the corrosion potential value $(-100$ up to $+75 \mathrm{mV} /$ Ecor $)$ in order to prevent the risk of artificial corrosion. We can notice that the corrosion rate is very low during the whole immersion duration, even if the Ecor values become more negative.

Table 3: Electrochemical results of long immersion test

\begin{tabular}{|c|c|c|}
\hline & E cor $(\mathrm{mV} / \mathrm{SCE})$ & $\mathrm{I}$ cor $\left(\mu \mathrm{A} / \mathrm{cm}^{2}\right)$ \\
\hline at the immersion & -184 & 0.09 \\
after 24 h of immersion & -157 & 0.01 \\
after 32 h of immersion & -286 & 0.10 \\
after 48 h of immersion & -345 & 0.15 \\
\hline
\end{tabular}

\section{CONCLUSION}

The laser powder cladding technique allowed to produce 304 and 316 austenitic stainless steel clad layers with a good metallurgical bond with the substrate and a low level of dilution. If the 304 coatings were sound, unfortunately the 316 clad layers contained always cracks. The absence of cracks was related to the presence of a significant amount of $\delta$-ferrite. Primary solidification of the $\delta$ phase seems thus favourable to prevent hot cracking of the strainless steel layers. Corrosion properties could be tested on the crack-free 304 clad layers : in every case, very low current densities were measured indicating an excellent uniform corrosion resistance.

\section{REFERENCES}

[1] RENAUD L., FOUQUET F., MILLET J.P. and CROLET J.L., Surface and Coatings Technology 45 (1991) 449.

[2] WEERASINGHE V.M, STEEN W.M, WEST D.R.F., Surface Engineering 3 (1987) 147.

[3] SINGH J. and MAZUMDER J., Metallurgical Trans. A 19A (1988) 1981.

[4] SALLAMAND P. and PELLETIER J.M., Mat. Sci. and Eng. A 171(1993), 263.

[5] BROOKS J.A., THOMPSON A.W., International Materials Reviews 36 (1991) 16. 